\title{
CELESTINA: A LIFE
}

\section{Dorothy Sherman Severin University of Liverpool}

Who was Celestina? A native and denizen of the city portrayed in the work as she tells Sempronio: 'En esta ciudad nacida, en ella criada, manteniendo honra como todo el mundo sabe, ¿conocida no soy'?' (81). According to her own account to Melibea she was the youngest of four sisters, and a widow (93): 'Pero también yo encañecí temprano y parezco de doblada edad. Que así goce de esta alma pecadora y tú de ese cuerpo gracioso, que de cuatro hijas que parió mi madre, yo fui la menor. Mira como no soy vieja, como me juzgan.' Her husband's name is unknown, although he is referred to in the first act, cryptically, as a 'comedor' or 'encomendador de huevos asados' (60). If the first reading is correct, he was a Jew or a converso (Goldman), if the latter reading, the expression seems to be a rude one, but its exact nieaning is unknown, possibly 'cornudo' (Gillet, Escudero). Of Celestina's younger years we know little. Was she in fact a prostitute, as her penultimate words to Sempronio imply?: '¿Quién soy yo, Sempronio? ¿Quitásteme de la putería?' (182). Did early widowhood drive her back into more nefarious means of making a living?: 'Que con mi pobreza jamás me faltó, a Dios gracias, una blanca para pan y un cuarto para vino, después que enviudé; que antes no tenía yo cuidado de lo buscar, que sobrado estaba un cuero en mi casa y uno lleno y otro vacío' (93). She was certainly incapable of having children with her husband or perhaps at all, and so became a universal auntie, or surrogate mother, to the younger members of our story who call her 'madre' (Hawking).

Of her younger mature years we know that she became best friend and possible lover, as well as apprentice, to Claudina: 'Juntas comíamos, juntas dormíamos, juntas habíamos nuestros solaces, nuestros placeres, nuestros consejos y conciertos' (81). Claudina's official job was midwife or 'partera' for sixteen years (122), a job which Celestina also practised, for example, at Pármeno's birth (81) and at Calisto's birth twenty three years before our action begins: 'Podía ser, señora, de veinte y tres años, que aquí está Celestina, que le vido nacer y le tomó a los pies de su madre' She also learned to be a sorceress from Claudina and she was once arrested and publicly shamed with her, a fact 
mentioned by both Lucrecia (88) and Pármeno (123): ¡Jesú, señora!, más conocida es esta vieja que la ruda. No sé cómo no tienes memoria de la que empicotaron por hechicera, que vendía las mozas a los abades y descasaba mil casados'(88). Claudina however was arrested four more times alone, the last for witchcraft, although Celestina denies the charge despite a description of some of Claudina's practices which indicate the summoning up of demons:

¿Qué más quieres, sino que los mismos diablos la habían miedo? Atemorizados y espantados los tuvo con las crudas voces que les daba. Así era ella de ellos conocida, como tú en tú casa. Tumbando venían unos sobre otros a su llamado. No le osaban decir mentira, según la fuerza con que los apremiaba. Después que la perdí, jamás les oi verdad. (123)

It seems as though this may have been the stage at which Celestina took Pármeno into her house as an adoptive son, while his father Alberto was still alive (67). Claudina's fate is not spelled out but she seems likely to have been condemned, from the hints which we are given in the text. (124-25; Severin, 1997). Pármeno was so small when he briefly lived with Celestina (perhaps he was somewhere between 5 and 7 years old) that Celestina is surprised that he can remember anything about her ('Pero muy pequeño eras tú. Yo me espanto cómo te acuerdas, que es la cosa que más olvidada está en la ciudad,' 123-24), so this was perhaps fifteen years earlier: remember that he served the 'frailes de Guadalupe' for nine years before entering into service with Calisto.(176).

It seems that before the death of Claudina, Celestina was already experiencing her salad days of twenty years earlier when according to her own account she ran a bawdy house with nine young girls between the ages of 14 and 18 in her charge: 'Yo vi, mi amor, a esta mesa, donde agora están tus primas asentadas, nueve mozas de tus días, que la mayor no pasaba de dieciocho años y ninguna había menor de catorce' (150). This presumably was at the tumbledown house by the tanneries which is several times mentioned as her previous location $(60,67,88,92)$. 'Tiene esta buena dueña al cabo de la ciudad, allá cerca de las tenerías, en la cuesta del río, una casa apartada, medlo caída, poco compuesta, y menos abastada' (60).

This is the right place to have a house of prostitution, and although Pármeno's description of it doesn't quite tally with Celestina's, she may have being remembering the derelict slum with rose-tinted glasses. According to Pármeno the prostitution racket was not a public one but was concealed by a front business of a seamstress shop, and the prostitutes were only in the parttime employ of Celestina, as they were servant girls who went to Celestina's from their own mistresses' houses, allegedly to help with the sewing and mending (60), although this was also a pretext for handling stolen goods from the 
girls' employment as well as other more important thefts. This front business is still part of Celestina's trade and her way of gaining entry to houses: the skein of thread is the pretext for entering Pleberio's house and talking to Melibea for the first time. Then as now Celestina was also involved with the clergy, although trade is not nearly as good as it used to be according to her account at the banquet scene, and the 'ministro gordo' who Celestina invents to deflect Sempronio from discovering Crito with Elicia in Act I may owe a lot to wishful thinking on Celestina's part: 'Pues servidores, ¿no tenía por su causa de ellos? Caballeros viejos y mozos, abades de todas dinidades, desde obispos hasta sacristanes' (151).

Sir Peter Russell asked a number of years ago why Celestina had moved house and Eukene Lacarra supplied the answer with documentation of how the ayuntamientos took over the mancebias, as they were euphemistically called, to stop the spread of syphilis in the mid-nineties. In fact Celestina has made the move only two years earlier, according to Melibea (92), whose parents had moved into a good river-view neighbourhood not too far from Celestina's bad one some six years before, a house with all modern conveniencess, tower, garden, refreshing breezes. Celestina is a bit optimistic when she refers to them as her neighbours for four years (117), they may have lived nearby, but certainly not on the river beside the malodorous tanneries. Russell pointed out some other mysteries about Celestina's new house which still need to be solved. She has moved lock stock and barrel to what seems to be a better location in a twostory house with attic and terrace, taking her furniture with her, or at least the table on which the banquet is held in Act IX, that much is certain: 'Yo vi, mi amor, a esta mesa, donde agora están sus primas asentadas, nueve mozas de tus días' (150).

She also has taken the paraphernalia of her many trades, and rather than the cámara described by Pármeno she now seems to have the stuff stored in an attic room by a roof terrace and in another upstairs room with ointments. ('Pues sube presto al sobrado alto de la solana y baja acá el bote del aceite serpentino. Entra en la cámara de los ungüentos y en la pelleja del gato negro donde te mandé meter los ojos de la loba, le hallarás' [...] 84,85). Despite her protestations of poverty, according to Elicia the rent is actually paid up a year in advance: 'Allí quiero estar, siquiera porque el alquiler de la casa está pagada por ogaño, no vaya en balde' (203). And although she is forbidden to run a house of prostitution she seems to get away with having a single high-class prostitute, Elicia, in her employ. One wonders if the ayuntamiento has paid off Celestina rather than just closing her down. A three-year lease on a decent house in a more salubrious neighbourhood would have seemed a good deal to a sixtyish old woman whose actuarial prospects were fairly dim at that point. The ayuntamiento might have wanted to keep the tanneries premises for their own operation, buying her goodwill, so to speak. However the childless Celestina was 
sturdier than most women of her age, despite her sudden obvious decline over the past two years which is noted by Melibea: 'Así goce de mi, no te conociera, sino por esa señaleja de la cara. Otra pareces, muy mudada estás. No es tan poco tiempo dos años [...]' (92).

She was beginning to panic about the future and protest her poverty and decline to the point of a reckless avarice. Thus she extracts from the well-heeled Calisto the promise (never fulfilled) of a manto and a saya (113), a hundred gold pieces (74), and a valuable gold chain (167) worth at least half a mark. Not bad for a single commission, but necessary to feather her nest in the absence of a full-scale prostitution racket, and with old age stretching out before her beyond the final year of her lease. Of course maybe we are being too ingenious here and Elicia's words about the paid rental simply indicate that Celestina had already spent the first part of her earnings from Calisto, the hundred gold pieces, on securing her lodgings for another year. And the word ogaño may indicate a period of less than a year, perhaps a quarter.

Returning to Pármeno's narrative of his life with Celestina, she plied six trades, seamstress, perfumer, cosmetician, mender of virgins, go-between and sorceress specialising in love magic (60). But he also mentions folk-healer ('hacíase física de niños', 61), as does Lucrecia who makes the more inflated claim of thirty 'oficios', but only adds herbalist and lapidary to our list (88). Certainly the herbs are in her laboratory but not the stones which would have had healing and even magical qualities, other than the stone from the eagle's nest from Rojas's sources Mena and Lucan, and which was used for magic (62). Her job as curandera is called on by both Areúsa for whose 'mal de madre' she prescribes strong-smelling substances (128; Lacarra) and Melibea, for whose love sickness she prescribes Calisto (159).

Celestina herself insists on three other qualities which she emphasises, although not strictly speaking jobs or occupations. She insists frequently that she is poor or a poor widow, she refers on several occasions to the fact that she is a lover of wine (93-94), a vice which she shared with Claudina and perhaps learned from her (82), and she is an avid churchgoer in pursuit of her prey (151), although she also offers prayers on her beads for Alisa's sick sister: 'Yo te prometo, señora, en yendo de aquí me vaya por esos monesterios, donde tengo frailes devotos míos, y les dé el mismo cargo que tú me das. Y además de esto, ante que me desayune, dé cuatro vueltas a mis cuentas' (90). This is not only a joke about her so-called devout friars and a hypocrisy in the circumstances, but also an activity typical of folk-healers (recall the blind man in Lazarillo). On her use of the church for business Sempronio gives us a vivid account (142) as does she in the banquet scene (151). 'Cuando hay que roer en casa, sanos están los santos; cuando va a 1a iglesia con sus cuentas en la mano, no sobra el comer en casa' (142). And she also describes her religious activities in the banquet scene 
of Act IX: 'En entrando por la iglesia, veía derrocar bonetes en mi honor, como si yo fuera una duquesa. El que menos había de negociar conmigo, por más ruin se tenía. De media legua que me viesen, dejaban las Horas' (151). And of course she famously calls for confession as she is being murdered (184, Deyermond).

How old is Celestina? Not as old as she looks, as she tells Melibea, she has had a hard life as attested by the disfiguring scar on her face (92-93). She admits to sixty when she is being attacked by Pármeno and Sempronio (183), but according to Pármeno she is seventy-two ('seis docenas de años acuestas', 78). However he makes a more modest estimate of about sixty-four when he says 'Esta puta vieja querría en un día por tres pasos desechar todo el pelo malo, cuanto en cincuenta años no ha podido medrar' (107), if we calculate her adulthood from, say, 14. Pleberio must also be about her age of 60 since he married at 40 and his only daughter is 20 . Alisa's lack of other children also suggests the possibility of a mature union at say, 35, although it may just indicate bad luck in childbearing or infant and child mortality.

If we look at Celestina's oficios we can see how one grows from another and they are joined together in a circle. The folk-healer is a midwife, a herbalist and a lapidary, who also supplies bath oils, perfumes, and other cosmetics, as well as love potions and at times black love arts to her clients, who may also need the services of a go-between and then a virgin-mender from the former madam, who disguises her profession with the front of seamstress and churchgoer, which brings us back to prayers for the sick and folk-healer.

Equally we can detect a circular web in Celestina's relationships with the other characters. Celestina's teachers were Alberto and Claudina, and their son Pármeno is her surrogate child, whom she at times treated abusively. 'Y algunas veces, aunque era niño, me subías a la cabecera y me apretabas contigo y porque olías a vieja, me huía de ti' (67). He serves Calisto, whom Celestina brought into the world as midwife, as she had Pármeno. Sempronio, Calisto's other servant, is lover of Elicia, Celestina's housekeeper and prostitute whose grandmother taught Celestina to mend virgins (133), while Elicia's cousin Areúsa, Eliso's daughter (70), is made to entrap Pármeno, and her other cousin, Lucrecia, serves Melibea, whose parents Pleberio and Alisa were Celestina's neighbours and who is in turn bewitched by Celestina and Calisto. 'No seas la telaraña' (98), Melibea is told by Celestina, but Celestina herself seems to be the spider sitting in the middle of this web of young adults and older contemporaries (Blay \& Severin). She uses her thread and her net to catch young girls: 'En naciendo la mochacha, la hago escribir en mi registro, y esto para que yo sepa cuántas se me salen de la red' (81).

As I pointed out thirty years ago in Memory in 'La Celestina', Celestina is the one figure who lives in memory and for whom the most extensive back- 
ground can be drawn up. But looking at the casual remarks dropped by the other characters as well, we can reconstruct a biography and an autobiography which, despite a few mystifying lacunae and chronological puzzles, gives us a rounded portrait of the type of folk-healer-cum-sorceress and bawd who would be persecuted and driven out of business across Europe during the sixteenth and seventeenth centuries.

$x * x$

\section{WORKS CITED}

Blay Manzanera, Vicenta \& Dorothy S. Severin, Animals in 'Celestina', Papers of the Medieval Hispanic Research Seminar (London: Dept. of Hispanic studies, Queen Mary and Westfield, 1999).

Escudero, Juan M. 'La expresión "comedor/encomendador de huevos asados" en la Celestina: nuevos asedios interpretativos,' Rivista di Filologia e Letterature Ispaniche 1 (1998), 197-201.

Gillet, J. E., "'Comedor de huevos" (?): La Celestina, Aucto I," Hispanic Review 25 (1956): 144-147.

Goldman, Peter B., 'A New Interpretation of "comedor de huevos asados" (La Celestina, Aucto I),' Romanische Forschungen 77 (196): 363-367.

Hawking, Jane, 'Madre Celestina,' Annali del Istituto Orientale Napoli-Sezione Romanza, 9 (1967), 77-90.

Lacarra, María Eugenia, 'El fenómeno de la prostitución y sus conexiones con La Celestina', in Historias y ficciones: Coloquio sobre la literatura del siglo XV, eds. R Beltrán, J. L. Canet \& J. L. Sirera (Valencia: Universitat, Dept. de Filologia Espanyola, 1992), pp. 267-278.

Michael, Ian, 'Por qué Celestina muda de casa,' in Actas do IV Congresso da Associação Hispânica de Literatura Medieval, eds. A. A. Nascimento \& C. A. Ribeiro (Lisbon: Cosmos, 1993), III: 69-89.

Russell, Peter E., 'Why Did Celestina Move House?,' in The Age of the Catbolic Monarchs 1474-1516: Literary Studies in Memory of Keith Whinnom (Liverpool: Liverpool UP, 1989), pp. 155-161.

Severin, Dorothy S., ed. Fernando de Rojas, La Celestina (Madrid:Alianza,1969). , Memory in 'La Celestina' (London: Tamesis, 1970).

, 'Was Celestina's Claudina Executed as a Witch?', in The Medieval Mind: Hispanic Studies in Honour of Alan Deyermond, eds. I. Macpherson \& R. Penny (London: Tamesis, 1997), pp. 417-424.

,Witchcraft in 'Celestina', Papers of the Medieval Hispanic Research Seminar, 1 (London: Department of Hispanic Studies, Queen Mary and Westfield College, 1995). 